\title{
A Gallic Affair: The Case of the missing Itch-Mite in French Medicine in the early Nineteenth Century
}

\author{
DANIÈLE GHESQUIER*
}

The "itch-affair" is usually presented as a scientific fraud perpetrated by a student named Jean-Chrysanthe Galès (1783-1854) in his medical thesis, in 1812. The "affair" has been told many times, but none of the versions defends Galès, although his guilt was never demonstrated. ${ }^{1}$

The itch (in French "la gale") is a disease characterized by violent itching, pimples and scabs on the skin. Today it is accepted that the itching is due to an insect, the sarcoptes, burrowing tunnels into the dermis in order to deposit its eggs, cutting through both the dermis and the small vessels in its path. The tissue reacts, creating small vesicles filled with a serous, transparent liquid, a mixture of cellular fragments and blood. If the itch is not cured, these vesicles enlarge, and fill with pus, thereby becoming pustules. Patients treated for the itch in Parisian hospitals often suffered from an advanced stage of the disease, which explains why the itch was also called psoris pustulosa. ${ }^{2}$ For his thesis, Galès removed the sarcoptes from the early vesicles. ${ }^{3} \mathrm{He}$ observed them under the microscope and compared them with early descriptions of the itch-insects. To discriminate between the sarcoptes and the flour-mite (which is very similar), Galès reproduced the itch by "inoculating" himself with the sarcoptes, thus demonstrating that the itch was caused by the sarcoptes and not by the flour-mite.

In the years that followed, however, it proved impossible to find the sarcoptes on itchinfected persons. Moreover, the figures in Galès' thesis, which depicted the flour-mite and

*Danièle Ghesquier, INSERM Unit 158 Hôpital Necker, 75015 Paris, France.

I am especially indebted to John Pickstone and Ilana Löwy for reading previous versions of this article and for their insightful comments. I am also grateful to my colleagues from INSERM U 158 and particularly Anne-Marie Moulin, François Delaporte, Patrice Pinell and Jean-Paul Gaudillière for their advice and encouragement. I also wish to thank the referees and especially Jackie Duffin.

${ }^{1}$ Giuseppe Penso, La conquête du monde invisible: parasites et microbes à travers les siècles, Paris, Roger Dacosta, 1981, p. 269. See also A Devergie, 'Hôpital St Louis. Leçon clinique sur la gale', Gazette des hôpitaux, 11 Sept. 1852, p. 429; Louis Brodier, J L Alibert, médecin de l'Hôpital
Saint-Louis (1768-1837), Paris, Maloine, 1923, pp. 9-10; Achille Alfaric, Alibert, fondateur de la dermatologie en France, sa vie, son oeuvre (1768-1837), Paris, Baillière et fils, 1917, pp. 32-43; Jean Théodoridès, 'Réflexions sur l'histoire de la parasitologie', Médecine de France, 1954, 58: 3-7; J T Crissey and L C Parish, 'The gentle stranger', in idem, The dermatology and syphilology of the XIXth century, New York, Praeger, 1981, pp. 60-79, on p. 61; B Dujardin, 'L'histoire de la gale et le roman de l'acare', Archs. Belg. dermat. syphil., 1946, 2 : 13-75; ibid., 1946, 3: 1-49; ibid., 1949, 3: 129-75.

$2 \mathrm{~J}$ L Alibert, Description des maladies de la peau, Paris, Barrois, 1806 and 1825, pp. 235-38.

3 J C Galès, 'Essai sur le diagnostic de la gale, sur ses causes, et sur les conséquences médicales pratiques à déduire des vraies notions de cette maladie', medical thesis, Paris, 1812, p. 20. 


\section{The Missing Itch-Mite in French Medicine}

not the sarcoptes, led to the accusation that his work was a hoax: that he had falsified his experiments, showing the flour-mite (which was easy to find) instead of the itch-sarcoptes to the members of his thesis jury.

Twenty-two years later, in 1834, Simon-François Renucci, another medical student, rediscovered the sarcoptes in the tunnels burrowed by the insect in itch-infected skin. The previous unsuccessful attempts to find the sarcoptes were explained by the fact that investigators searched only the vesicles or the pustules (the advanced stage of the vesicles), and that nobody (since 1812) had thought to explore the tunnels. The insect's localization strengthened suspicions about Galès, for it was thought that he had claimed to have found the sarcoptes in the itch-pustules. In fact, Galès investigated only the "early vesicles" which, unlike the late pustules, occasionally contain the sarcoptes, but his contemporaries ignored this detail. Two indications seemed to make Galès guilty: his thesis drawings of the flour-mite, and the localization in the pustules. ${ }^{4}$

It had been known for centuries that the sarcoptes was found in the skin. An English physician had written before 1604 that the insect lived in the tunnels and not in the pustules. ${ }^{5}$ More than a century before Galès' thesis, the mechanism of itch-contagion had already been explained by an Italian physician who found the insect in the itch-vesicles. ${ }^{6}$ Moreover, Carl von Linnaeus (1707-78) confused the itch-insect and the flour-mite and classified them as two varieties of the same species. ${ }^{7}$

If everything was known about the itch in the early nineteenth century, why was Galès obliged to make the demonstration again for his thesis? Had the cause of the itch been forgotten, and if so, why? Were the experimental conditions concerning the recognition of the sarcoptes so different that Galès should be blamed for a fault for which Linnaeus had been forgiven? If the Italian, the first "discoverer" of the role of the sarcoptes, found the insect in the itch-vesicles, why was Galès condemned for doing the same? And finally, why did sarcoptes searchers obstinately continue, after Galès' thesis, to investigate the itch-vesicles or pustules instead of the tunnels?

This "exploration" of the history of the itch will examine all the conditions which, in 1812, led a physician at the Hôpital Saint-Louis in Paris to ask one of his students to "show" the itch-sarcoptes, and which, between 1812 and 1834, made the sarcoptes "disappear". It will pay special attention to the changes in the general theory of disease, prevalent in France between the 1810s and the 1830s, and to the development of the concept of specific causes of specific diseases. Only in this way can one grasp what underlay the "itch-affair".

\footnotetext{
${ }^{4}$ Penso, op. cit., note 1 above, p. 269. See also Devergie, op. cit., note 1 above, p. 429.

5 Thomas Moffett, Insectorum sive minimorum animalium theatrum, London, Thom. Cotes, 1634, quoted in Thomas Bateman, Abrégé pratique des maladies de la peau classées d'après le système nosologique du Docteur Willan, translated by Guillaume Bertrand, Paris, Plancher, 1820, pp. 254-5.
}

\footnotetext{
${ }^{6}$ Giovanni Cosimo Bonomo, Osservazioni intorno a' pellicelli del corpo umano, Florence, Piero Matini, 1687, quoted by Penso, op. cit., note 1 above, p. 160.

${ }^{7}$ Alibert, op. cit., note 2 above, p. 252. See also G H Walz, De la gale des moutons, de sa nature, de ses causes, et des moyens de la guérir, Paris, Huzard, 1811, p. 60.
} 


\section{From the Mite's Discovery to Galès' Thesis}

The disease known today as "itch" has been known since the antiquity. ${ }^{8}$ It was classified as a "scabies", a name signifying "rough skin" which encompassed very different skin diseases. The first reported connection between an animal and the disease was made in the twelfth century by the Arab physician Avenzoar. ${ }^{9}$ In France, the medical writings of Guy de Chauliac (1300?-67), ${ }^{10}$ Ambroise Pare (1509-90), ${ }^{11}$ as well as the novels of François Rabelais (1490?-1553), ${ }^{12}$ and popular medical books ${ }^{13}$ mentioned this minute itch-animal called the mite.

Despite the numerous observations of mites, this association between a skin disease and a live animal was not a one-to-one relationship because what was then referred to as the itch included all diseases which made the skin rough (scabies), and the mite was found in only some of these. Moreover, in Aristotle's definition of a parasite, the mite is "an animal which was born spontaneously in other animals". ${ }^{14}$ It was believed that the parasite did not reproduce sexually, but was produced by the corrupted humours of the disease.

\section{Lower Animals are Living Beings which are Causes of specific Diseases}

During the seventeenth century, the development of the microscope and the changing theories of generation resulted in the inclusion of worms and mites among "insect" species, which reproduced like higher animals. Many observers described the mite (which became an acarus in 1557) ${ }^{15}$ associated with the itch. ${ }^{16}$ Among them, Thomas Moffett (1553-1604) wrote that the insect lived in tunnels which it burrowed in the skin. ${ }^{17}$ Giovanni Cosimo Bonomo (1663-96) and Diacinto Cestoni (1637-1718) were, however, the first to state that the acarus was responsible for itch symptoms, while clarifying the contagious aspect of this disease in 1687:

Mites, like all animal races, reproduce from a male and a female. I tend to think that the "itch", called scabies by Latins, and described as a contagious skin disease, is nothing more than a bite or nibble in the skin by the said little worms, accompanied by continuous itching ... It is not hard to see why the itch is so contagious. By simple contact between two bodies, the mites can pass from one to the other, ever ready to attach themselves to anything and after choosing a place to nest, they deposit their eggs and multiply in large numbers ... Neither is it surprising that contagion is passed on via sheets, towels, table napkins, gloves and other objects often handled by itch-infected persons,

${ }^{8}$ Deuteronomy, 28:27, quoted by Penso, op. cit., note 1 above, p. 26.

${ }^{9}$ Abumeron Avenzoar, Theisir, Venice, J et G de Gregoriis, 1490, quoted by Penso, op. cit., note 1 above, p. 81 .

${ }^{10}$ La grande chirurgie de Guy de Chauliac composée en l'an 1363, Paris, E Nicaise, F Alcan, 1890, quoted by Penso, op. cit., note 1 above, p. 93.

${ }^{11}$ Les oeuvres de M Ambroise Paré, conseiller et premier chirurgien du Roy, Paris, Gabriele Buon, 1575, quoted by Penso, op. cit., note 1 above, p. 117 .

${ }_{12}$ François Rabelais, La vie inestimable du grand Gargantua père de Pantagruel, jadis composée par l'abstracteur de quinte essence. Livre plein de pantagruelisme, Lyon, F Juste, 1535, quoted by
Penso, op. cit., note 1 above, p. 116.

13 Sequel to the collection of easy domestic remedies by Madame Fouquet published in Paris in 1687 by "L'imprimeur aux âmes charitables", pp. 16 and 132.

${ }^{14}$ Aristotle, Aristotelis opera omnia Graece et Latine cum indice nominum et rerum absolutissimo, Paris, Firmin Didot, 1878, quoted by Penso, op. cit., note 1 above, p. 48.

${ }^{15}$ Giulio Cesare Scaligero, Exotericarum exercitationum, Paris, 1557, 1634 ed. quoted by Penso, op. cit., note 1 above, p. 117.

16 Penso, op. cit., note 1 above, p. 157.

${ }^{17}$ Moffett, op. cit., note 5 above, quoted by Bateman, op. cit., note 5 above, pp. 254-5. 
where the mites can lodge themselves. Actually, mites can live outside the body for up to two or three days as I myself have observed several times. ${ }^{18}$

Bonomo's and Cestoni's description of the acarus as the agent of the itch led to two disputes: the first was with Francesco Redi (1626-98), who questioned the priority of the observations of the two discoverers. ${ }^{19}$ The second was with Giovanni Maria Lancisi (1654-1720), who claimed that not all scabies were due to the acarus. ${ }^{20}$ Bonomo also said that the animals could be found in numerous small waterfilled vesicles, although sometimes he did not find them in such sites. ${ }^{21}$ This observation was associated with the vague name of "scabies", a nosological term based solely on the appearance of the skin. Later, the fact that Bonomo did not clinically define the itch was seen as a significant obstacle to finding the acarus; failures were attributed to the vagueness of the term "scabies". 22 A close look at the course of events shows, however, that this was not the only reason for the lack of success in uncovering the acarus.

Other parasitic insects of humans and plants were observed during the seventeenth century. ${ }^{23}$ Many of these caused irritation, and all seemed to reproduce sexually. ${ }^{24}$ The itch-acarus fitted this pattern. Scientists observed that, when the insect disappeared, so did the skin affection. Therefore, the insect was clearly the cause of the disease and not a product of it. "Tiny worms" or animalcules were observed by Carlo Francesco Cogrossi (1682-1769) in 1713, during an Italian cattle epidemic. ${ }^{25}$ Cogrossi compared this causation to that of human itch, and concluded that each contagious or epidemic disease was a specific disease caused by the sudden multiplication of its own type of "vermin". 26 Benjamin Marten expressed the same opinion in England in 1720 with regard to consumption, ${ }^{27}$ as did Jean-Baptiste Goiffon in France in 1721 with reference to the plague. ${ }^{28}$ This theory was supported by Linnaeus (who classified the itch-acarus and the flour-mite as belonging to the same species) ${ }^{29}$ and John Nyander, ${ }^{30}$ and also by the smallpox model which showed that a inoculated substance collected from pustules caused only smallpox and no other disease. ${ }^{31}$

18 Bonomo, op. cit., note 5 above, quoted by Penso, op. cit., note 1 above, p. 160.

${ }^{19}$ Penso, op. cit., note 1 above, p. 161.

${ }^{20}$ Ibid., pp. 161-2.

${ }^{21}$ Bonomo, op. cit., note 6 above, quoted by Penso, op. cit., note 1 above, p. 161.

22 Ibid., p. 161.

${ }^{23}$ Willelm Le Pois, Historia naturalis Brasiliae, Leiden, F Hack, 1648; see also Marcello Malpighi , Opera omnia, London, Robert Littlebury, 1687, both quoted by Penso, op. cit., note 1 above, pp. 144-52.

24 Penso, op. cit., note 1 above, pp. 150-52.

${ }^{25}$ Carlo Francesco Cogrossi, Nuova idea del male contagioso de' Buoi, Milan, 1714, quoted by Penso, op. cit., note 1 above, p. 222.

26 Ibid., p. 223.

${ }^{27}$ Benjamin Marten, A new theory of consumption: more especially a Phthisis or consumption of the lungs, London, Printed for $\mathrm{R}$ Knaplock, 1720, quoted by Penso, op. cit., note 1 above, p. 224.

\footnotetext{
28 Jean-Baptiste Goiffon, 'Dissertation sur la peste pour servir de réponse à Messieurs Lemoine et Bailli, Docteurs en médecine de la faculté de Paris, envoyés par la Cour en la province de Gavandan', in Relations et dissertations sur la peste de Gavandan, Lyon, Pierre Valfray, 1722, quoted by Penso, op. cit., note 1 above, p. 225.

${ }^{29}$ Alibert, op. cit., note 2 above, p. 252.

${ }^{30}$ Margaret E DeLacy and A J Cain, 'A Linnaean thesis concerning contagium vivum: the exanthemata viva of John Nyander and its place in contemporary thought', Med. Hist., 1995, 39: 159-85. See also, Johannes Carolus Nyander, 'Exanthemata viva', thesis submitted 23 June 1757 and published in Amoenitates Academicae seu dissertationes variae physicae, medicae, botanicae antehac seorsim editae nunc collectae et auctae cum tabulis aenis, ed. Carl Linneaus, Leiden, Wetstenium, 1760, V, pp. 92-105.

31 DeLacy and Cain, op. cit., note 30 above, p. 165.
} 


\section{Danièle Ghesquier}

However, the concept of the specificity of diseases did not originate from the description of specificity of disease-inducing "vermin". It arose from the observations that a given disease always reproduced with the same symptoms and the same periods, and, in addition, that it could be cured by a "specific" drug. ${ }^{32}$ The diseases appeared like entities and were classified by nosologists as if they were plants. ${ }^{33}$ At the beginning of the nineteenth century, the development of pathological anatomy allowed a disease to gain another level of specificity since it was identified with its specific lesions. ${ }^{34}$ Thus, Gaspard Laurent Bayle (1774-1816), in 1810, affirmed that "tubercles" in the lung were specific to consumption. ${ }^{35}$

\section{The Model of Contagion by Animalcules Disappears, to be Replaced by the Virus Model of Smallpox}

At the beginning of the nineteenth century, the most widespread destructive diseases were collective diseases. Two theories attempted to explain their mechanism of transmission: infection and contagion. Several definitions of both theories coexisted, often contradictory and imprecise. ${ }^{36}$ The main difference between the concepts of contagion and infection was that the agent of contagion was defined as a specific virus, ${ }^{37}$ the description of which was often that of the pus found in pustules of contagious diseases: "The virus is a substance which is usually fluid, deposited locally in a person with a certain disease, containing a specific property which makes it able to infect a healthy person and to determine the reproduction of a similar disease: a venereal virus, the dartrous virus etc. .... ${ }^{38}$ The analogy of pus with sperm explained the generative power of the virus (the contagious principle) ${ }^{39}$ that a few people still explained as multiplication of "animalcules". 40 The model for contagious diseases was smallpox. It had clearly-defined features: contagion through scabs and pustules, exanthemata, pruritus, infection through contact, and protection by inoculation. ${ }^{41}$

The itch was also viewed as a contagious disease. However, at the beginning of the nineteenth century, there was no agreement on the nature of itch contagion. The observations made by Bonomo and Cestoni were forgotten. In England in 1703, Richard

\footnotetext{
32 Bernardino Fantini, 'Le rôle du concept de spécificité dans la pensée médicale', in A Bouchet (ed.), Conférences de l'Institut d'histoire de la médecine, Lyon, Collection Fondation Marcel Mérieux, 1994, pp. 73-83, on p. 76.

${ }^{33}$ Knud Faber, Nosography. The evolution of clinical medicine in modern times, 2nd ed., New York, Paul B Hoeber, 1930, p. 28. See also, W F Bynum, Science and the practice of medecine in the nineteenth century, Cambridge University Press, 1994, p. 15. See also, Fantini, op. cit., note 32 above, p. 75.

${ }^{34}$ Michel Foucault, La naissance de la clinique, Paris, Presses Universitaires de France, 1963, pp. 177-98. See also Fantini, op. cit., note 32 above, p. 77; Faber, op. cit., note 33 above, p. 28.

${ }^{35}$ Gaspard Laurent Bayle, Recherches sur la phthisie pulmonaire, Paris, Gabon, 1810, pp. 21-6.
}

\footnotetext{
36 Jean-Joachim-François Cattet and JeanBaptiste-Joseph Gardet, 'Essai sur la contagion', medical thesis, Paris, year X (1802), introduction pp. xx-xxx. See also, Joseph Bressy, Théorie de la contagion et son application à la petite vérole, à la vaccine, à leurs inoculations, et à l'hygiène, Paris, Gabon, year XII (1803-1804), p. 12. See also François Delaporte, Le savoir de la maladie, Essai sur le choléra de 1832 à Paris, Paris, Presses Universitaires de France, 1990, pp. 135-72.

${ }^{37}$ Bressy, op. cit., note 36 above, p. 31 .

38 Cattet et Gardet, op. cit., note 36 above, introduction $\mathrm{p} . \mathrm{xxj}$.

${ }^{39}$ Bressy, op. cit., note 36 above, p. 48.

${ }^{40}$ Cattet et Gardet, op. cit., note 36 above, p. 369.

${ }^{41}$ Margaret Pelling, Cholera, fever and English medicine, 1825-1865, Oxford University Press, 1978, pp. 17-18.
} 


\section{The Missing Itch-Mite in French Medicine}

Mead (1673-1754) mentioned them in the Philosophical Transactions, and towards the middle of the century Linnaeus and his students incorporated them in their writings. ${ }^{42}$ But fifty years later, the theory of contagium animatum by itch-mites was challenged by other theories including the itch "virus" theory.

Contagion of the itch was addressed in two books published in the early nineteenth century: extensively in the medical thesis of Cattet and Gardet, ${ }^{43}$ and more briefly in the monograph on contagion by Bressy. ${ }^{44}$ In both books, the authors agreed with the theory of a virus contained in the pus of the pustule: "Medical practitioners and authors unanimously agree on the contagion of this disease. It is caused by the psoric virus ... and is transmitted through contact with the acrid liquor contained in the pustules of the sick person". 45 They stated that the insect was the supposed cause of the itch; however Cattet and Gardet did not connect contagion with the presence of the acarus and only described "the acrid liquor" in the pustules. By contrast, Bressy suggested that the pus was corrupted by the animal venom, thereby accounting for the presence of the insect. ${ }^{46}$ Thus the pus of the itch-pustule was the contagious principle; the acarus became secondary.

\section{Galès' Thesis}

From the end of the eighteenth century there was an upsurge of cases of the itch in France, probably caused by poor hygiene in towns, and the arrival of waves of immigrants from the rural areas to the city. The Pastoret report, written in 1816, indicates that, at the St Louis hospital, 700 beds (of a total of 1100) were assigned to itch patients: 400 for men, 300 for women; 450 for simple itch cases and 250 for more complicated ones. Infected nursing mothers were placed in a separate building. The itch affected a large number of factory workers and domestic servants who were subsequently dismissed from their jobs. Employers were afraid of the contagion, and the infected persons were unable to find work for as long as the effects of the itch were visible on their bodies. ${ }^{47}$ The disease was seen as a serious problem, for example for wet-nurses who contaminated the children entrusted to them, for soldiers, and for the poor. ${ }^{48}$

The severity of the disease also seemed to have been underestimated:

It is dangerous to have this disease for a long time without treating it because it completely disorganizes the skin and afterwards there are chronic ulcers and unending abscesses which reappear at intervals ... Who would have thought that a disease so harmless in appearance could have such sinister effects, could cause infected persons to lose weight and make them waste away and suffer

\footnotetext{
${ }^{42}$ DeLacy and Cain, op. cit., note 30 above, pp. 165 and 178.

43 Cattet et Gardet, op. cit., note 36 above, pp. 217-19.

44 Bressy, op. cit., note 36 above, p. 55.

45 Cattet et Gardet, op. cit., note 36 above, pp. 217-19.

${ }^{46}$ Bressy, op. cit., note 36 above, p. 55.

${ }^{47}$ M Pastoret, Rapport fait au Conseil Général des Hospices, Paris, Huzard, 1816, pp. 72-3.

48 After the Revolution, France was in conflict until 1815 with all other European countries. Alibert
}

cites the cases of 6000 itch-infected soldiers out of service, cured by first using black soap followed by rubbing the skin with alkaline hydrosulphur. As for the poor, Alibert said they were received at night hostels which were no better than gutters, and that naturalist physicians would do well to set up their observatories in these places ( $\mathrm{J}$ L Alibert, Clinique de l'hôpital Saint Louis, ou traité complet des maladies de la peau, contenant la description de ces maladies et leurs meilleurs modes de traitement, Paris, B Cormon et Blanc, 1833, pp. 312 and 306). 


\section{Danièle Ghesquier}

from consumption; who would have thought that it would cause the integuments to deteriorate to the point of stopping all bodily functions $?^{49}$

Once the itch was widely recognized as a contagious disease, it became of utmost importance to separate infected persons from the healthy and to prevent sufferers from having contact with other people until they were no longer contagious. The special hospital for itch-infected persons which Jacques Tenon (1724-1816) had called for in 1788 was seen as an efficient way to achieve this goal. ${ }^{50}$

\section{The Hospital for Skin Diseases becomes the Hospital for the Itch}

By 1812, when Galès was defending his thesis, a special hospital, the St Louis hospital, had been made available in Paris for the treatment of the itch. This specialization has a history.

The St Louis hospital was built by order of Henri IV in 1607, on the outskirts of Paris, to isolate plague victims during epidemics. The hospital was carefully designed to prevent contagion through contact: "The St Louis hospital was different from other hospitals for fever patients and for the wounded in that it had double walls and the double courts around it cut off all communication with the town". ${ }^{51}$ Over the following centuries, the hospital admitted patients of various epidemics in Paris: the plague, cholera, smallpox, typhus and scurvy. ${ }^{52}$ When there was no epidemic, the hospital cared for patients suffering from various chronic alterations and ulcerations of the skin, for example, the itch, tinea, scurf, scurvy, ulcers, scrofula, cancer, and syphilis; people who could easily be sent home in the event of an epidemic. ${ }^{53}$ This "specialization" was approved by the Consulate on 27 November $1801 .^{54}$

After 1801, most of the beds at St Louis hospital were occupied by itch patients, creating a problem of space. But the fairly successful treatment of choice, dry fumigations recommended by the chief pharmacist, Galès, required hospitalization. Moreover, this avoided the spread of the disease:

It is the difficulty of isolation, of changing clothes and linen; the problem of precautionary measures and preventive care and often their impossibility which spreads the disease among the indigent. The

${ }^{49}$ Alibert, op. cit., note 2 above, p. 236.

${ }^{50}$ Tenon, a professor of pathology at the school of surgery, believed that the itch was a contagious disease. He noticed that itch-infected persons being treated for surgical disease, at the Hôtel-Dieu hospital, transmitted the itch to the other patients. In a very short time, 1200 people had the itch. Tenon believed that the contagion could be indirect as well: "The contagion spreads via mattresses and feather beds which are constantly being tranferred between Hôtel-Dieu and St Louis hospitals. We need to have a hospital where people can be treated for the itch, because it is a social problem" ( $\mathrm{J}$ Tenon, Mémoire sur les hopitaux de Paris, Paris, Royez, 1788, pp. 195-8, and p. 344).

51 Tenon, op. cit., note 50 above, p. 400.

52 P N Ste Fare-Garnot, Histoire de l'Hôpital Saint Louis, Paris, Ed. de l'Arbre à Images, 1986, pp. 69-71.
53 Tenon, op. cit., note 50 above, p. 357.

54 The Consulate and the Empire completely reorganized the structure of Parisian hospitals by separating general and specialized hospitals and by creating a central admissions office under the 4 December 1801 decree. St Louis became the Northern hospital, was autonomous and specialized in chronic diseases, whether contagious diseases such as the itch or tinea or stubborn and cachetic diseases such as scurf, scurvy, ulcers and scrofula. This specialization was made official by a decree passed by the general council of hospitals on 27 November 1801 (Ste Fare-Garnot, op. cit., note 52 above, p. 23 and pp. 74-5. See also Brodier, op. cit., note 1 above pp. 9-10, and Alfaric, op. cit., note 1 above, pp. 32-43). 
sick worker, for example, fears that he will be dismissed by his employer and so hides his disease for as long as he can and continues to have contact with his friends thereby transmitting the disease to them. At the hospital, the infected are separated from those to whom the disease could be transmitted. The infected are given fresh clothes and linen during the treatment and theirs are disinfected. The treatment does not need to last for 6 weeks, 2 months or more. Twenty days is sufficient. $^{55}$

\section{Alibert and the Itch}

Thus, by the early nineteenth century, St Louis hospital had become a special hospital for "skin diseases", and a young physician, Jean-Louis Alibert (1766-1837), was put in charge. Alibert had graduated from the famous Ecole de santé de l'an III (1794). He presented a thesis on intermittent ataxic fevers which was republished several times. Alibert had been taught by Philippe Pinel (1745-1826) and was a friend of Pierre Cabanis (1757-1808), Xavier Bichat (1771-1802) and Paul-Joseph Barthez (1734-1806). Along with Bichat, he founded the Société Médicale d'Émulation. He was a Idéologue philosopher, a sensualist and a supporter of Etienne Condillac's (1715?-80) analytical method. He was sympathetic to medical vitalism and to the experimental doctrine of sensitivity and irritability. His contemporaries saw him as learned, full of humour and possessing an indefatigable gift for observation, open to novelty but also critical. ${ }^{56}$ Alibert was appointed chief medical officer at St Louis hospital in 1807 and became passionately interested in skin diseases. He classified them, hoping thereby to facilitate differential diagnosis and open the way to more varied and effective treatments. He gave the first lectures on the subject; his research and his philosophical writings made him famous. In 1818 , he was appointed personal physician to Louis XVIII. ${ }^{57}$

The specialization of the Parisian hospital, combined "the powerlessness of the patients with an enormous size of the hospital system, [and] provided the clinicians with an inexhaustible fund of acquiescent research material. Clinicians thus gained control over and autonomy within the technical process of production of medical knowledge". 58 Alibert was able to make a great number of observations (for instance, he saw 14,600 cases of tinea dermatoses over a period of twenty-two years), ${ }^{59}$ and to learn about the variability of pathological conditions:

As I worked in an operating theatre where these diseases were constantly being treated, I was the best person to throw some light on the confusion which had characterized previous work. I was able to monitor the progress, the phases, the decline, the resurgences and the evolution of different exanthemata. It was in the hospitals that the different characteristics were most evident because we were able to follow them through all the stages of their development. ${ }^{60}$

It was probably the increase in itch cases, combined with the fact that infected persons of no fixed address had to be isolated for twenty days, which enabled Alibert to establish

\footnotetext{
55 Pastoret, op. cit., note 47 above, p. 73.

56 Brodier, op. cit., note 1 above.

${ }^{57}$ Ibid. See also Alfaric, op. cit., note 1 above.

$58 \mathrm{~N}$ D Jewson, 'The disappearance of the sickman from medical cosmology, 1770-1870', Sociology, 1976, 10 (2): 225-44, on p. 235. See also Dora B Weiner, The citizen-patient in revolutionary
}

and imperial Paris, Baltimore and London, Johns Hopkins University Press, 1993, pp. 15, 166-90, and 304-19.

${ }^{59}$ Brodier, op. cit., note 1 above, p. 15.

${ }^{60}$ Alibert, op. cit., note 2 above, discours préliminaire, p. i. 


\section{Danièle Ghesquier}

that only one psoric disease (scabies) deserved to be called itch and that was the contagious type:

When I started my clinical research at the St Louis hospital, it was not long before I realized the extreme confusion that reigned in the history of psoric diseases. Alterations of the dermal system were usually all given the name itch although their only relation to this affection was to produce numerous pimples accompanied by violent and constant itching. I then decided to determine the distinctive characteristics of this new species of exanthema in order to identify the treatment which was best suited to it. Prurigo was essentially different from the itch in that it was not contagious. The itch, on the other hand, was transmitted only through contagion. Naturalists had already classified the devouring insect which propagated the disease. ${ }^{61}$

In his classification, Alibert made a distinction between pustular psora, papular psora and squamous psora, based on the appearance of the lesion and associated symptoms. He focused his attention on pustular psora (psoris pustulosa) which, according to him, corresponded to the itch, the only contagious psora. He rejected the idea of humoral disorders, as explained by the humoral theory, ${ }^{62}$ as valuable for other psora but not for the itch:

Among the diseases of which we intend to give the history, we have noticed that there are some which are obviously due to an internal cause, such as a particular defect which is gradually introduced into the lymphatic system; but there are others with external causes attributable to the presence of certain animalcules whose form and configuration have been the object of specific study by naturalists. ${ }^{63}$

The itch was one of those diseases with an external cause, in this case an insect:

The evolution of natural history and its close ties with medicine have helped us to understand for some time now how insects contribute to producing cutaneous diseases. We now know that a number of exanthemata are due to irritation that can be caused by the presence of these insects in the dermal system ... What is remarkable is that each animalcule provokes an alteration which is specific to it ... some nest and perpetuate their stay in the organ ... When it is hot, swarms of flies produce no less fearful phenomena than extraordinary tumefactions. ${ }^{64}$

Alibert was convinced that itch contagion had one single cause, the insect which was given the name sarcoptes in 1806 . He did not even mention the possibility of a virus, an idea cherished by most contagionists (including Bichat), ${ }^{65}$ and he firmly opposed infectionist theories on the transmission of disease by a miasma generated by poor hygiene or by a substance in the "humours".66

Although it is true that uncleanliness, with its usual attributes, may be a favourable condition for papulo-squamous psoras, it would be wrong to apply this to the itch, although I will not deny that lack of hygiene could play an important part. But the fact that this affection is commonly found among the lower classes and seems inherent, in a way, to poverty, does not necessarily mean that these causes, which can prolong the disease, are enough to produce it. One decisive proof, in this

${ }^{61}$ Ibid., pp. iv-v.

62 Muriel Laharie, La folie au Moyen-Âge, XIe-XIIIe siècles, Paris, Le Léopard d'or, 1991, pp. 120-2.

${ }^{63}$ Alibert, op. cit., note 2 above, p. 233.

64 Ibid., p. xj.

${ }^{65}$ Anatomie pathologique. Dernier cours de
Xavier Bichat. D'après un manuscrit autographe de $P$ A Béclard; avec une notice sur la vie et les travaux de Bichat, par F G Boisseau, Paris, J B Baillière, 1825 , p. 232.

${ }^{66}$ Humoral theory, see Laharie, op. cit., note 62 above; pp. 120-22. 


\section{The Missing Itch-Mite in French Medicine}

respect, is that persons in the upper echelons of society who keep themselves clean, who frequently change their linen and observe the most rigorous practices of hygiene are not exempt from pustular psora. Furthermore, once the disease develops, these observances are not enough to destroy it. There is, therefore, one other cause for the affinity of this disease, if I may express it in this way, for persons of condition, fortune and opposite habits and this cause is obviously to be found in its contagious principle, that is in the sarcoptes.

Alibert said that before the aetiology of pustular psora was discovered, physicians had thought that a fermentable substance or an acrid principle was responsible. "We are surprised that it took so long to arrive at the truth on a point of pure intuition because it seems humoral hypotheses would naturally fail when faced with so many cases of itch which developed instantaneously and in the presence of bounding health. But as a philosopher said, man cannot see because he finds it easier to imagine!"67

Alibert was convinced that the sarcoptes was not an effect of the itch. If this was the case, from where did this insect come? He did not know: "some think of spontaneous generation like for fleas. But this is mere conjecture. What is certain is that the insect is the cause of the itch and uncleanliness favours its appearance". ${ }^{68} \mathrm{He}$ was familiar with the medical literature, especially Bonomo and Cestoni's work on the reproduction and transmission of the mite, ${ }^{69}$ and yet he thought that the mite was reproduced by spontaneous generation, probably without realizing that this might make the mite accessory to the disease.

His attitude probably reflects the perplexity among early nineteenth-century scientists concerning animal generation and origins of disease. Seventeenth-century naturalists had shown that all higher animals reproduced by sexual generation, but they had also shown that some little animals called "animalcula" like the itch-acarus, reproduced differently (for instance, the plant-louse). During the eighteenth century, several theories strengthened the idea of spontaneous generation. Many scientists observed sexual generation in lower animals, but at the same time, they affirmed that these animals could also be engendered by spontaneous generation; the two statements were not seen as contradictory. For example, Jean-Baptiste de Lamarck (1744-1829) believed in 1802 that the itch-acarus was the product of spontaneous generation. ${ }^{70}$

Alibert's main concern was not to study the acarus generation, but to demonstrate that the sarcoptes was the cause of the itch, and to discriminate between the itch and other types of "scabies". However, he had first to prove the existence of the mite to people who had never seen it and who believed that the itch was a product of uncleanliness:

It was against the background of these brilliant works (from previous centuries) that further research was, nevertheless, carried out in order to observe the existence of this insect in a more rigorous way. The research was done in my presence at the St Louis hospital and was a result of the zeal and shrewdness of M Galès who devoted three entire months in 1812 to this task. A Faculty of Medicine commission, of which I was a member, and another commission from the Academy of Science, were often present at these experiments and in this way, each Commission member was able to see the small animal which had been the object of such intense searches. ${ }^{71}$

${ }^{67}$ Alibert, op. cit., note 2 above, p. 252.

${ }^{68}$ Ibid., p. 253.

69 Ibid., p. 252.

${ }^{70}$ Lamarck questioned the generation of "intestine worms, of some vermin responsible for skin diseases or moulds, varied mushrooms, even lichens" (JeanBaptiste de Lamarck, Philosophie zoologique, Paris, F Savy, 1873, vol. 1, p. 214; vol. 2, pp. 81-2).

${ }^{71}$ Alibert, op. cit., note 2 above, p. 252. 


\section{Danièle Ghesquier}

\section{Galès Reproduces the Itch Experimentally}

On 21 August 1812, Galès defended his medical thesis: 'Essai sur le diagnostic de la gale, sur ses causes, et sur les conséquences médicales pratiques à déduire des vraies notions de cette maladie' (Essay on the diagnosis of the itch, its causes and the practical medical consequences to be deduced from the true notions of this disease). It was because of his name that Galès, who was at that time chief pharmacist at St Louis hospital and a medical student, was directed by Alibert (who had a good sense of humour) to defend a thesis on the itch. ${ }^{72}$

Galès started his thesis by mentioning early descriptions of the sarcoptes by Avenzoar and Moffett, and, according to him, by Cestoni. ${ }^{73} \mathrm{He}$ added that Cestoni's work had been forgotten because it was not in agreement with the opinions of his time. Galès conducted two kinds of experiments: first, observations under the microscope (he claimed he had used a good microscope) and then inoculations. The sarcoptes that he observed under the microscope were drawn "larger than life" by Meunier (the artist), following the advice of the entomologist Pierre-André Latreille (1762-1833). ${ }^{74}$ As a result, Galès' observations were disconcerting, since the drawing of the sarcoptes was different from that represented in the works of Cestoni, Michael Ettmüller, and Carl De Géer. Galès concluded that several species of itch-mite existed because the mite he described looked exactly like the flour-mite drawn by De Géer. He saw how Linnaeus could have confused the two mites, and, therefore, tried to compare the two insects under the microscope. What he saw did not help him to differentiate the flour- and the itch-mite, as they were very similar. Then, he began inoculation experiments to identify which of the two caused the itch. He placed each insect separately under a watch-glass fixed on his arm. The flour-mites did not induce skin symptoms; by contrast, the itch-mites produced characteristic ulcerations verified by Louis Bosc, Guillaume Olivier, André Duméril (1774-1860), Latreille and Anthelme Richerand (1779-1840). He then got rid of the mites quickly (unfortunately, he was not explicit about the means used), for fear of spreading the disease. ${ }^{75}$

Galès observed the sarcoptes extensively; it was difficult for him to find the insect, but, after a while, he could recognize the occupied vesicles at a glance: "one reliable way to find the insect is to explore preferably the smallest pimples, those of which the serosity is the clearest ... The insect leaves the vesicle as soon as it has produced it: it is necessary to catch it before its escape ... They [the insects] gather on the articulations and spread via the numerous eggs they lay". Galès said that to get rid of the disease, it was not enough to kill the mites, it was necessary to destroy the eggs. To the question: "Is it the insect which gives the itch, or the itch which produces the insect?", he replied "ambiguous generation" was contradicted by analogy and observation. If the mite was accessory, how could the cure that killed it make the disease disappear? Those who thought otherwise confused all varieties of scabies. ${ }^{76}$

\footnotetext{
72 Théodoridès, op. cit. , note 1 above, pp. 3-7. See also Crissey and Parish, op. cit., note 1 above, pp. 60-79, on p. 61; F V Raspail, 'Mémoire comparatif sur l'histoire naturelle de l'insecte de la gale', Bulletin général de thérapeutique, 1834, 7 : $169-87$, p. 171.

${ }^{73}$ It is generally accepted that Bonomo and Cestoni together discovered the role of the acarus in
}

the itch, but Cestoni was never quoted alone, since he only observed the insect (under the microscope).

${ }^{74} \mathrm{P}$ Latreille was the entomologist who gave the name of sarcoptes to the mite. He was a member of the Science Academy commission that judged Galès' work.

${ }^{75}$ Galès, op. cit., note 3 above, pp. 22-6.

76 Ibid., pp. 22-33. 
Galès' dissertation was illustrated with an itch pustule. The epidermis was removed to reveal the inside containing an oblong mite with four pairs of legs, and with a young mite with only six legs. ${ }^{77} \mathrm{He}$ had to prove the existence of the mite and its role in the itch. Since the end of eighteenth century, "scientific" proof had to be provided with reproducible evidence, devoid of any subjective element, in order to satisfy the scientific community. ${ }^{78}$ In the case of the itch only two kinds of proof could be given: seeing the mite by means of a microscope, which allowed comparison with known pictures, and the reproduction of the disease.

Galès obtained his degree; it is obvious, therefore, that the members of the examining board approved his results. He himself said that his mite resembled a flour-mite, and it is probable that the examiners agreed with him. He also explained that Linnaeus had made the same observation half a century earlier, establishing that the two mites were two varieties of the same species. In his thesis, he emphasized the great similarities among mites; he used the example of the sheep itch acarus recently discovered by $\mathrm{G} \mathrm{H} \mathrm{Walz},{ }^{79}$ which has a body more oblong than that of the human itch acarus, and less oblong than that of the flour-mite.

Moreover, in 1812, microscope examinations were not a generally accepted scientific proof. Famous doctors, such as Bichat, Cabanis and Armand Trousseau (1801-67) were hostile to the instrument. ${ }^{80}$ Some people claimed that microscopic images were artefacts, not true pictures of reality. And those who conceded that the microscope might reflect reality thought that the objects seen were too small to be of any importance. Besides, the compound microscope invented c. 1600, gave spherical aberrations until Joseph Lister (1786-1869) used an achromatic lens in $1829 .{ }^{81}$ Thus, only a few knew how to use the instrument and physicians often sent their preparations to someone else for microscope observations. We have seen that, in the seventeenth century, Bonomo entrusted the microscope observations of his mites to the pharmacist Cestoni who was an expert microscopist. Furthermore, many of those who were familiar with the use of the microscope, were incapable of differentiating between the cheese-mite, the human itchmite and the sheep itch-mite. It is, therefore, understandable that at the time when Galès wrote his thesis microscope observations were considered, at best, as an auxiliary proof.

The second proof that Galès invoked was inoculation: he "inoculated" himself with both types of mites. This experiment invites two comments: one on the practice of selfinoculation, the other on the transformation of the meaning of the word "inoculation". Self-experimentation was frequently used in medicine during the nineteenth century. $\mathrm{L} \mathrm{K}$ Altman records that, on 17 October 1808, Alibert permitted a colleague to inject him twice with a sample of liquid material from a woman who had a cancer of the breast. The same material was also injected into a medical student and two of Alibert's colleagues. ${ }^{82}$ It is thus not surprising that Galès used this practice to obtain the proof he was looking for.

\footnotetext{
${ }^{77}$ Ibid., p. 54. The sarcoptes of the human-itch is not oblong but round like a tortoise.

${ }^{78}$ Christian Licoppe, 'Eprouver, rapporter et convaincre. Une étude du compte-rendu expérimental à l'époque moderne', $\mathrm{PhD}$ thesis, Paris, 1994.

${ }^{79}$ Walz, op. cit., note 7 above, pp. 17-19 and pp. $68-70$.

${ }^{80}$ Erwin H Ackerknecht, Medicine at the Paris
}

hospital, 1794-1848, Baltimore, Johns Hopkins University Press, 1967, p. 93.

${ }^{81}$ Gerard L'Estrange Turner, 'The microscope as a technical frontier in science', in idem, Essays on the history of the microscope, Oxford, Senecio, 1980, pp. 159-83.

${ }^{82}$ Lawrence K Altman, Who goes first? The story of self-experimentation in medicine, New York, Random House, 1987, p. 286. 


\section{Danièle Ghesquier}

\section{Still the Smallpox Model}

Galès reproduced the symptoms of the itch by "inoculating" himself with the mite. The term "inoculation" was not usually used in that sense. It came, as seen earlier, from the typical exanthema model-smallpox. The similarities between the two diseases had initially led Alibert to classify them as belonging to the same family. Because they were both contagious, gave rise to epidemics (this was sometimes questioned), and were characterized by the appearance of pustules on the skin, the reasoning that had been used for the more familiar smallpox was also applied to the itch.

The contagious principle of smallpox was not known, although some suspected animalcules. ${ }^{83}$ But the contagious principle was known to reside in the pus contained in the pustules which, when inoculated, transmitted smallpox and protected the body against further attacks of the disease. Cowpox, also called vaccinia, conformed to the same model as smallpox. Contagion was transmitted by the pus in the pustules which also protected against smallpox. It was thought that the contagious principle for itch was also contained in the pustules, and several doctors, among them Alibert, injected the pustular liquid in order to reproduce the itch:

Shall we speak about contagion? what an abundant source of diseases for the human skin! but also what obscure phenomena to unveil! Each cutaneous affection has its own transmission channel, so to speak. At St Louis hospital, I discovered that nothing differs more than the way in which dermatoses propagate. Smallpox and vaccinia can develop through the introduction of some leaven into the absorbent vessels but this is not the case for the itch, which I tried, without success, to produce through inoculation. ${ }^{84}$

After the unfruitful attempts to inoculate the itch, the term "inoculation", used to designate the "introduction into the organism of a substance containing the germs of the disease", was probably adapted to the itch model by Galès' contemporaries. The inoculation was made, not with the pus from the pustules, but with their contents, that is, the sarcoptes which was supposed to contain the contagion principle.

\section{Galès' Experiments cannot be Reproduced}

When Galès defended his thesis, most doctors were open to a range of possible interpretations of disease. By the 1820s, however, the definition of infection and contagion had become more precise. The majority of experts admitted that contagion, by direct contact, was a virus effect, and that infection was an indirect effect, transmissible by water, air or infected objects. ${ }^{85}$ Moreover, anti-contagionist views were ascendant, and only a few exceptions were allowed. Unless communicable diseases fitted strict criteria of specificity (contagion through scabs and pustules, reproduction and protection by inoculation with the specific virus), they were interpreted as chemical disturbances, caused by environment miasma. ${ }^{86}$ In the 1820 s, the influence of "physiological medicine"

\footnotetext{
${ }^{83}$ Cattet and Gardet, op. cit., note 36 above, p. 363.

84 Alibert, op. cit., note 2 above, discours préliminaire, p. $\mathbf{x}$.

${ }^{85}$ Margaret Pelling, 'Contagion, germ theory, specificity', in W F Bynum and R Porter (eds), Companion encyclopedia of the history of medicine,
}

2 vols, London and New York, Routledge, 1993, vol. 1, pp. 309-34, on pp. 309 and 321-3.

${ }^{86}$ Faber, op. cit., note 33 above. See also Delaporte, op. cit., note 36 above; Ann F La Berge, Mission and method: the early nineteenth-century

French public health movement, Cambridge 
swept away the last bastions of specificity. The re-interpretation of the itch was, I propose, part of a major re-ordering of disease theory, caused, in part, by shifts in medical politics.

\section{The Disease becomes Aspecific}

As already shown, during the seventeenth and eighteenth centuries parasites were recognized as specific animals causing pathological phenomena, but this view did not lead directly to the idea of specificity of disease. The idea of specific animals causing specific diseases was, however, conserved in the animalcules theory. According to Margaret Pelling and Owsei Temkin, the obstacle to the development of the animalcule theory of disease was of a philosophico-religious nature: among German "Naturphilosophen" and their French collaborators, diseases were themselves seen as organisms, developing within humans and exhibiting their own specific forms. The exponents of chemical medicine and the hygienists condemned theories of an animalcule origin of diseases as speculative ${ }^{87} \mathrm{~K}$ Codell Carter proposes a different reason why an animalcule theory did not develop: pathological anatomy focused on internal processes rather than on external causes. ${ }^{88}$ Diseases were viewed as the non-specific results of living conditions. By the 1820 s, most doctors were strongly focused on chemical theories of disease causation, and contagion was mainly interpreted chemically. Diseases lost their specificity. It was with this reasoning that François-Joseph-Victor Broussais (1772-1838) rejected Pinel's ideas on the entity and the specificity of the disease in L'examen de la doctrine médicale généralement adoptée (Examination of the generally adopted medical doctrine) (1816).

Broussais thought that disease was provoked by cold air, drugs, miasmas or noxious substances in the atmosphere, and by moral or psychological influences, that is, by causes foreign to the functioning of the organ which determined an inflammation, a sign of a functional attack on the tissue, resulting in the lesion. There was only one aspecific therapy for this aspecific disease: leeches and bloodletting used to reduce sanguine congestion. This therapy was applied to the cure of syphilis and smallpox. ${ }^{89}$ Some historians propose that ' $L$ 'examen, in 1816 , had the same shock effect on medical thinking as Sieyes' famous brochure, 'What is the third estate?' had had in 1789". 90 Disease became a deviation from normal function which was the cause of the pathological lesion. ${ }^{91}$ This theory, which connected hygienist and infectionist ideas to the notion of lesion developed by pathological anatomists, was adopted enthusiastically by the majority of the medical community. Broussais was supported by medical students, military physicians, health officers, some civilian physicians, and by the public who attended his

University Press, 1992; Pelling, op. cit., note 85 above, and Erwin H Ackerknecht, 'Anticontagionism between 1821 and 1867', Bull. Hist. Med., 1948, 22 (5): 562-93.

${ }^{87}$ Pelling, op. cit., note 85 above, p. 316 . See also Owsei Temkin, 'The scientific approach to disease: specific entity and individual sickness', in idem, The double face of Janus, Baltimore, Johns Hopkins University Press, 1977, pp. 441-55, on p. 443.

${ }^{88} \mathrm{~K}$ Codell Carter, 'Koch's postulates in relation to the work of Jacob Henle and Edwin Klebs', Med. Hist., 1985, 29: 353-74, on p. 364.
${ }^{89}$ F J V Broussais, Examen de la doctrine médicale généralement adoptée, et des systèmes modernes de nosologie, dans lequel on détermine, par les faits et par le raisonnement, leur influence sur le traitement et sur la terminaison des maladies, Paris, Gabon, 1816, pp. 412-60, see also idem, De l'irritation et de la folie, Paris, J-B Baillière, 1839 , vol. 1, pp. 1-78.

$90 \mathrm{~J}$ L Peisse, La médecine et les médecins, 2 vols, Paris, J-B Baillière, 1857, vol. 2, pp. 400-1.

${ }^{91}$ Broussais, op. cit., note 89 above. 


\section{Danièle Ghesquier}

lectures. "In the 1820s the new fashion in medicine was the physiological doctrines of François Broussais". 92 Even many opponents (in the Faculty) were influenced by Broussais' ideas. ${ }^{93}$

The enthusiasm with which Broussais and his ideas were received did not prevent, however, a vociferous opposition, which came mainly from the pathological anatomists and from those E H Ackerknecht called the "Eclectics". 94 The therapeutical failures of Broussais (syphilis and cholera) and then the development of the "numerical method" by Pierre Louis (a method which allowed quantitative evaluation of the efficacy of therapies) raised doubts about anti-phlogistic therapeutics and thus about Broussais' theory. ${ }^{95}$ In addition, the study of specific organic lesions consolidated the concept of specific diseases. In 1819, René Laennec affirmed, after Bayle, that "tubercules" in the lung were a specific manifestation of consumption. ${ }^{96}$ In 1825 , Louis confirmed the specificity of consumption lesions. ${ }^{97}$ In 1829 , he described typhoid fever as a specific pathological entity. ${ }^{98}$ Léon Rostan recognized the existence of specific diseases in $1826 .{ }^{99}$ In 1834 , Auguste Chomel favoured the idea that typhoid fever was contagious. ${ }^{100}$ And Trousseau diffused the ideas of his teacher Pierre-Fidèle Bretonneau (1778-1862) on contagion and specific diseases.

From 1812, Bretonneau supported the notions of disease specificity and contagiosity. He was a pupil of Jean Corvisart and a friend of Bayle. His work on "dothiénentérie" and on diphtheria, led him to comment that "disease specificity is proven by so many facts that perhaps there is no truth which abounds more in demonstrations or is more fruitful . . . It is the more or less exact, clear or confirmed, admitted or tacit notion of a specific characteristic which has always been at the base of the diagnosis of most diseases . ..". Bretonneau said that, on the one hand, there was the existence of a specific germ (or seed) and on the other the coexistence of favourable terrain, in other words, predisposition. Those were the two conditions for specific and contagious affections. ${ }^{101}$ The means of contagion were also specific: "a disease can be transmissible although not to the same extent and in the same way as smallpox", and "Diseases are not living beings, it is said everyday . . . However, many disorders which do not arise from spontaneous alteration of the organs, especially a large number of inflammations, are determined by extrinsic

\footnotetext{
92 George Weisz, The medical mandarins: the French academy of medicine in the nineteenth and early twentieth centuries, Oxford University Press, 1995, p. 193.

${ }_{93}$ Ackerknecht, op. cit., note 80 above, p. 64, See also, Jean-François Braunstein, Broussais et le matérialisme. Médecine et philosophie au XIX siècle, Paris, Méridien Klincksieck, 1986, p. 21.

${ }^{94}$ See Ackerknecht, op. cit., note 80 above, pp. 64-5 and ch. 8, and Braunstein, op. cit., note 93 above, pp. 87-97.

95 Braunstein, op. cit., note 93 above, p. 81.

${ }^{96}$ René T H Laennec, Traité de l'auscultation médiate et des maladies des poumons et du coeur, 3 vols, Paris, J A Brosson et J S Chaudé, Paris, 1819, vol. 1, p. 10.

${ }^{97}$ P C A Louis, Recherches anatomo-pathologiques sur la phtisie, Paris, Gabon, 1825, Rapport de l'Académie royale de médecine, pp. 1-16 and 2.
}

\footnotetext{
${ }^{98}$ Idem, Recherches anatomiques, pathologiques et thérapeutiques sur la maladie connue sous les noms gastro-entérite, de fièvre putride, adynamique, ataxique, typhoïde, bilieuse, muqueuse, entérite folliculeuse, dothiénentérie, etc, Paris, J-B Baillière, 1829, pp. 182 and 449-53.

${ }^{99}$ L L Rostan, Traité élémentaire de diagnostic, de prognostic, d'indications thérapeutiques, Paris, Béchet jeune, 1826, prolégomènes, pp. 77-80 and pp. 29-32.

${ }^{100}$ A F Chomel, Leçons de clinique médicale faites à l'Hôtel-Dieu de Paris par le professeur A Chomel, vol. I, La fièvre typhoïde, Paris, G Baillière, 1834, p. 539.

${ }^{101}$ Pierre-Fidèle Bretonneau, Des inflammations spéciales du tissu muqueux et, en particulier, de la diphtérite ou inflammation pelliculaire, etc, Paris, Crevot, 1826, pp. 366 and 243-74.
} 
material causes, by veritable beings which come from outside or at least, which are foreign to the normal state of the organ. The entozoons which frequently become uncomfortable and harmful to their hosts are beings and living beings". ${ }^{102}$

Bretonneau's ideas became dominant in the early 1830s, following the decline of Broussais' influence. Thus, between 1816 and 1830, very few people were concerned with specific causes of diseases.

\section{The English School supports the Itch-Virus}

Alibert was appointed personal physician to Louis XVIII, in 1818, at the height of the opposition to the idea of specific causation. Busy with his new job, he could no longer maintain his consultancy, or give lectures at St Louis and asked one of his favourite students, Laurent Biett (1784-1840), to replace him.

During a trip to England, Biett met Thomas Bateman (1778-1821), a physician who worked in a public dispensary in London, and who had promoted the classification of skin diseases of Robert Willan (1757-1812). Biett was taken with Willan's classification which agreed with the new medical ideas, and was simpler than Alibert's classification based on symptoms. ${ }^{103}$ Willan's classification-derived from a model developed by an Austrian physician, J J Plenck-was based solely on the morphological aspect of the cutaneous lesion, and it allowed for rapid diagnosis of the skin disease. Biett taught it on his return to St Louis hospital. ${ }^{104}$

In his book on Willan's system, Bateman included the itch. For him, all forms of the itch were contagious. Poor hygiene gave rise to the disease but it could also occur in wellto-do families which respected the rules of hygiene. He mentioned the insect which he had never seen personally, and he retraced the entire history of its discovery. He compared it to the cheese-mite and quoted his countryman Moffett, who had written that the insect did not live in the vesicles but in the tunnels. However, Bateman thought that the contagious nature of the itch was due to the liquid secreted into the pustules, which contained a virus. He did not attribute contagion to the existence of the insect. ${ }^{105}$ Thus, Bateman agreed with the prevailing opinion of his time about the itch.

But, on the other hand, it was the first time that an essay on skin diseases mentioned the tunnels in the skin in which the acarus buried itself, while everyone else was looking for it in the pustules. Alibert himself focused his attention on the pustules and ignored the tunnels. He was probably also taken aback by Bateman's aggressive attack on him at the beginning of his essay, an attitude which Breschet attributed to Bateman's "national spirit". ${ }^{106}$ Bateman also confused the different types of itch, probably because, unlike Alibert, he did not have itch patients at his disposal at the public dispensary.

\footnotetext{
102 Idem, Traités de la dothiénentérie et de la spécificité, Paris, Dr Dubreuil-Chambardel, 1922, pp. 249 and 342.

103 Alibert, op. cit., note 2 above.

104 Bateman, op. cit., note 5 above.

105 Ibid., pp. 253-56.

106 "M Alibert, with loud pretensions to superior skill, and much vaunting of the services which he has rendered this department of medicine, has, in fact, contributed nothing to the elucidation of the
}

\begin{abstract}
obscurity in which it is veiled. The merit of his publication belongs principally to the artists, whom he has the good fortune to employ. For he has adopted the ancient confusion of terms, without a single definition to fix their acceptation; and he has not scrupled to borrow the nomenclature of the vulgar, in its most vague and indeterminate sense" (Thomas Bateman, A practical synopsis of cutaneous diseases according to the arrangement of Dr Willan, London, Longman, 1817, pp. xii-xiii). See also
\end{abstract}




\section{Danièle Ghesquier}

It is not known whether Biett taught Bateman's version of the itch as he had taught the Englishman's classification of skin diseases, but the influence of the English school certainly started to be felt at St Louis hospital and in dermatological circles, as a result of the "Anglomania" which flooded France after the Restoration. ${ }^{107}$

\section{The First Supporter of the Itch-Mite becomes Unpopular}

A large part of what the medical world believed about the mite was the result of Alibert's influence. He was the only one to have shown any interest in the mite or to have lectured on it at the beginning of the century. However, Alibert's influence declined when he stopped teaching about skin diseases in 1819, and was replaced by Biett who was no longer a follower of his teachings. Moreover, Alibert was criticized because he exploited the fact that he held numerous offices. ${ }^{108}$ His junior colleagues at St Louis hospital and at the Faculty were left to do the work in positions for which Alibert enjoyed the title and remuneration, at a time when such posts were rare. ${ }^{109}$ There were four other physicians at St Louis at the same time as Alibert: Biett, Jean Lugol (1786-1851), Jean Manry (1783-1840) and Edouard Emery (1788-1856). ${ }^{110}$ Biett was the first who started to question Alibert's teaching when he imported the ideas of the English School. He replaced Alibert at St Louis for ten years, but he was only granted tenure six years after Alibert's departure. Objections came also from Lugol's department in the form of Ignace Mouronval's thesis, and certain rigged experiments. It is likely that Lugol's aggressive stance in the "affair" was influenced by Alibert's position as chief medical officer (a post Alibert continued to hold without really filling it and which he inopportunely took up again ten years later). Indeed, it was when Alibert returned to St Louis that the itch affair broke into outright scandal.

J Breschet, 'Analyse de l'ouvrage de Bateman', Journal de médecine, 1816, 58: 117 and 321.

${ }^{107}$ France was continually in conflict with England up to 1815. During the Continental System period, Napoleon's anglophobia was a reflection of a wider sentiment. Consequently, anglophilia became a means of fighting against Napoleon's authority. Certain royalist opponents sent their children to English boarding schools at the height of the Continental System period. In 1814 , peace with France united the two former enemies in such a bond of mutual enthusiasm and esteem that the humorists could say it all ended in kisses and songs. During the Restoration, the French were reading Shakespeare, Walter Scott and Byron. (J Lovie and A PalluelGuillard, Nouvelle histoire de la France contemporaine, t 5, L'épisode napoléonien, 2, Aspects extérieurs 1799-1815, Paris, Seuil, 1972, pp. 195-204.)

${ }^{108}$ In 1820, Alibert became a member of the Academy of Medicine; in 1821, he was appointed to the chair of botany at the Medical Faculty of Paris; in 1822, he was named chief inspector of the Enghien mineral waters; in 1823 he obtained the chair of therapeutics at the Medical Faculty of Paris; in 1827, Charles $X$ gave him the title of Baron. (Brodier, op. cit., note 1 above, pp. 307-17. See also Alfaric, op. cit., note 1 above, pp. 78-83.)

109 "The Revolution and the Empire called on young professionals to fill the void caused by emigration and war. The Restoration reduced the number of civil servants and did not create jobs. The birth rate in France was still high and the large number of middle-class youths often had no other prospect but to increase the number of lawyers without cases to defend and doctors without patients. There was a generational conflict which included clerks and a part of the liberal classes who had hard lives." (A Jardin and A J Tudesq, Nouvelle histoire de la France contemporaine, t 6, La France des notables, 1, L'évolution générale 1815-1848, Paris, Seuil, 1973, p. 65).

110 'Lettre de M. le professeur Hardy, Documents pour servir à l'histoire de l'hôpital St Louis au commencement de ce siècle. Alibert, Biett, Lugol, Manry, Emery', Annales de dermat., 2nd series, 25 Nov. 1885, 6: 629-38. 


\section{The Missing Itch-Mite in French Medicine}

Alibert's life style was also criticized. Parallel with his medical occupation, Alibert held a "salon littéraire" where he received artists and famous people for discussions of science, music, philosophy and poetry. Salons became fashionable again after the Restoration and were attended by adherents of the romantic literary movement. This activity did not conform with a physician's image, and the general disapproval of Alibert's life style was echoed in the press. ${ }^{111}$ In 1829 , an anonymous medical reporter wrote, after recalling Alibert's services to dermatology: "Nevertheless, these services were rendered twenty years ago; these twenty years are a century, and science is marching on". ${ }^{112}$

Finally, Alibert's political and philosophical opinions also worked against him because he was a royalist when most of the medical world was not. When the Bourbons returned in 1814 , the majority of the medical community was violently hostile to a regime which owed its existence to occupying armies, and under which the physician was again considered by the ruling class as a simple servant. Medical students took an active part in the political movements of the period. ${ }^{113}$ Alibert was a legitimist because he had been appalled by the horrors of the Terror, and because of his education and convictions (he was a priest before the Revolution). ${ }^{114} \mathrm{He}$ was also firmly attached to the religious ideas of the government and he ended up aligning himself with it by his adherence to spiritualist doctrine. ${ }^{115} \mathrm{He}$ was therefore highly unpopular with the majority of the medical community.

\section{The Mite is no Longer the Cause of the Itch}

The mite's existence and pathogenic role were challenged from 1821 . Since 1812, all Alibert's colleagues at St Louis hospital had followed his principles in their teachings on the itch, but they became concerned about having no proof of the mite's existence other than that presented by Galès. In 1821, Ignace Mouronval (1797-?), one of Lugol's students at St Louis, submitted a thesis entitled: 'Recherches sur les causes de la gale, faites à l'hôpital St Louis pendant les années 1819, 1820 et 1821' (Research on the causes of itch conducted at the St Louis hospital in 1819, 1820 and 1821).

Mouronval set about examining the causes of itch and he "obtained results which were entirely different from the generally accepted ideas". The cause of the contagion had recently been attributed to a psoric defect in the blood serum. For some years it had been thought that the natural cause of the itch was an insect, a mite, that the ancients and the Arabs had already described. ${ }^{116}$ This theory had been taught by Lugol for six years. Mouronval's results did not point to the mite as the only cause of the disease, because the insect had never been seen by him. He also explained that the mite Galès had shown did not look like Cestoni's mite, and he wondered whether it could change its appearance

\footnotetext{
${ }^{111}$ Brodier, op. cit., note 1 above, p. 63. See also Alfaric, op. cit., note 1 above, pp. 110-14; J H Réveillé-Parise, Gazette médicale de Paris, 30 March 1839, pp. 193-98, on p. 194; Louis Peisse, Les médecins français contemporains. M. Alibert, Paris, Gabon, 1827, pp. 57-68, on p. 65.

${ }^{112}$ La clinique des hôpitaux, 23 July 1829, p. 192.

113 Paul Triaire, Récamier et ses contemporains, Paris, J-B Baillière, 1899, pp. 170-1.
}

\author{
114 Alfaric, op. cit., note 1 above, pp. 10-1. \\ 115 A philosophical doctrine taught by Pierre \\ Royer-Collard (1763-1845) and Victor Cousin \\ (1792-1867) during the Restoration. \\ ${ }^{116}$ Ignace Mouronval, 'Recherches sur les causes \\ de la gale faites à l'hôpital St Louis pendant les \\ années 1819,1820 et $1821^{\prime}$, medical thesis, Paris, \\ 1821 , pp. 13-14.
}




\section{Danièle Ghesquier}

depending on who was looking at it (this was an attack on Galès' results). Inoculation with the liquid from the vesicles did not provide any further information. All Mouronval's results indicated that the psoric virus was not found in the pimples and nor was the mite. He concluded that the natural cause of the itch was neither a mite, nor a virus in the pimples (vesicles and pustules), but something unknown. ${ }^{117}$

Nine years after Galès' thesis the investigations were conducted very differently; Mouronval had a microscope at his disposal and, unlike Galès, did not to have to rely on a "montreur de boulevard" for his first experiments. ${ }^{118}$ It was probably the assiduous use of the microscope which made him so competent and enabled him to distinguish minute morphological differences such as those between spermatozoids and vinegar bacteria, not an easy task for his predecessors. It also enabled him to recognize the itch-mite, depicted in textbooks as Galès' mite, as the flour- or cheese-mite. ${ }^{119}$ In 1821 , the status of microscopic observations was higher than nine years earlier. This change was probably the result of greater use of the instrument due to the development of parasitology and microbiology, ${ }^{120}$ and of the advances in observation techniques and reagents which were refined by Raspail and amateur microscopists in the 1820 s. ${ }^{121}$ Later, in 1829 , after the "itch scandal" had erupted, Raspail made the following comment on the observation of the itch-mite : "Those who are accustomed to using the microscope for observation know very well how difficult it is to draw opaque objects of such small size; the reflecting glass, the amount of daylight, the shape of the microscope, and a host of other things can distort the image before one's eyes, especially if one does not devote several days to the study of the microscopic object"; ${ }^{22}$ and in 1834, he said:

It is becoming indispensable to use reagents that will make these opaque and indeterminable objects transparent enough to be seen properly through the use of a microscope. Thus, I successfully used concentrated acetic acid to look at how the points on the back of the insect were distributed. The insect is kept in the reagent for $\mathbf{2 4}$ hours, imprisoned in one of those apparatuses which I referred to in my [book] Organic Chemistry as reagent plates. This period is long enough to make the animal transparent by dissolving a large amount of the albuminous juice which had entered its system. ${ }^{123}$

Mouronval, like Galès, assumed that if the agent of the disease was to be found in the vesicles-pustules - the point of contagion - then the disease should be reproduced through "inoculation" with the agent. But, for Galès, the agent of contagion was the mite which he "inoculated" to reproduce the disease, while for Mouronval, it was the liquid in the

\footnotetext{
117 The study was carried out on 1867 itch patients of both sexes. Experimental conditions were tested on semen, vinegar and similar liquids where different animals of varying size and form were seen, moving in all directions which showed that the animalcules were quite visible and distinct under Mouronval's microscope (ibid., pp. 14-24).

118 A "montreur de boulevard" was someone who stood by the side of the road and allowed people to use his microscope for a fee (F V Raspail, 'La gale de l'homme est-elle le produit d'un insecte?', Annales des sciences d'observation, 1829, ii (3): 446-58, p. 453). However, Raspail was the only person to speak about Galès' "montreur de boulevard".
}

\author{
${ }^{119}$ In his various monographs describing skin \\ diseases written between 1812 and 1832 , Alibert \\ used the figures from Galès' thesis to illustrate the \\ chapter on the itch. \\ 120 Penso, op. cit., note 1 above, p. 253. \\ ${ }^{121}$ Brian Bracegirdle, A history of microtechnique: \\ the evolution of the microtome and the development \\ of tissue preparation, London, Heinemann, 1978, \\ p. 23. \\ 122 Raspail, op. cit., note 118 above, p. 451. \\ ${ }^{123}$ Raspail, op. cit., note 72 above, p. 177. See also \\ F V Raspail, Nouveau système de chimie organique \\ fondé sur des méthodes nouvelles d'observation, \\ Paris, J-B Baillière, 1833, p. 47.
}




\section{The Missing Itch-Mite in French Medicine}

pustules. Alibert, long before Galès' thesis, had concluded that the liquid did not transmit the itch, and that the mode of transmission was different to that of smallpox (see above). Mouronval reached a different conclusion: if the liquid in the pustules did not reproduce the itch, then it did not contain either a mite or a virus. The failure of his inoculation therefore raised doubts about the involvement of a "transmissible principle", either a virus or a mite, but not about the location of such a principle: "The natural cause of the itch is neither a mite nor a virus in the pimples; the cause of the itch is unknown". ${ }^{24}$

\section{Rigged Experiments Show that the Galès' Mite was the Cheese-Mite}

In 1821, immediately after Mouronval's thesis, rigged experiments concerning the itchmite were mentioned. The purpose of these was to show that Galès had passed off a flour(or cheese-) mite for an itch-mite, which probably did not exist. In 1824, Jacquemin Jr. and Lisfranc published a report of Mélier's work in the Journal général de médecine; François Mélier (a former resident student of Manry), one of Alibert's colleagues at St Louis, reported the results of experiments he had carried out on the treatment of the itch in 1821:

In an appendix to his work, $M$ Mélier mentioned useless experiments he and other physicians had done in order to observe the mite, the acarus scabiei. The transitory existence of this animalcule was very surprising; a few years ago, everybody had seen it and all the teachers spoke about it in their classes. Authors of several dissertations on the itch claimed to have seen the sarcoptes (the name conceived especially for it) run over their hands and they deliberately gave themselves the disease by placing the mite under a glass-watch on their wrist, in the crook of their elbow, etc. But since a student (Moronval) [sic] had written against the mite in the very place where it had allegedly been shown to exist, no one dared to continue saying they had seen it. Thus, like many others, the promite sect disappeared.

A passage in an article which appeared in your May issue, page 272, reminded me of something which took place three years ago [1821] at Hôtel-Dieu. Along with several of my colleagues, we searched elsewhere, apart from the books, for this object of widespread belief; after a few vain trials we gave up, when one of the company told us, quite confidently, that he was going to show it to us. He set up the microscope himself, pricked an itch pimple and stirred the substance collected on a watch-glass. We then distinctly saw a live animal, quite similar to the one shown in the Dictionnaire des sciences médicales. However, the rapid and easy success of this operation made us suspect it was a trick which the young man's smile confirmed even further. Indeed, he had placed, on the glass, some Gruyère cheese-mites. That was only a joke but it showed the extent to which people can play on the trust of observers. If he had done it with a bit more flourish, he would have convinced us that the mite existed.

In his article entitled 'Réponse aux assertions de $\mathrm{M}$ le professeur Alibert' (Response to the assertions of Professor Alibert) which appeared in the Gazette des hopitaux civils et militaires of 19 August 1834, Lugol also wrote that one day in 1829, in his absence, a marine surgeon named Meynier deceived the students in his department by showing them the famous acari (it was later revealed that the whole affair had been instigated by Raspail): "he had taken them from the pocket of his waistcoat containing the cheese powder which he had placed on each vesicle". The strategy of both experiments was

124 Mouronval, op. cit., note 116 above, p. 24. 


\section{Danièle Ghesquier}

designed to make the students believe that the demonstration of the itch-mite had been a hoax on Galès' part.

These two anecdotes illustrate well the fact that in the nineteenth century trust in familiar persons continued to be important in the making of modern scientific knowledge, as it had been in the seventeenth, and that modernity did not affect qualitatively the way in which that trust was accorded. ${ }^{125}$

\section{Scandal Erupts}

In April 1829, Alibert resumed his classes on skin diseases at St Louis. The itch controversy which had been dormant for ten years then broke out. The conflict arose between the students of Alibert who believed in the mite and those of Lugol who refused to believe in its existence. Arnal, a resident student at St Louis hospital, recounted this memorable occasion in the Lancette française of 28 July 1829: Alibert was very convincing; he recalled all those who had described and seen the insect; and Arnal asked: "What do you say to $M$ Galès who, one fine day, took up the insect by one of its many legs, put it on his hand and next morning felt that it had dug a complete little apartment in the thick part of his skin? . . . and didn't the same M Galès see him mate? . ..”. Arnal's satirical tone reflected the incredulity of Lugol and his students. Lugol, who was present at the lesson, was not convinced by Alibert; and Emmanuel Patrix, one of Alibert's students, offered to show him the object of contention. Lugol offered a reward of 300 francs to the student who could demonstrate the existence of the sarcoptes to him. One student cried out jokingly: "I have twenty stuffed ones".

It was the perfect opportunity for the other controversy to erupt, the one concerning the new classification of skin diseases which Alibert had drawn up in response to that proposed by Bateman, his rival from the English School. Alibert's classification was thought to be just as outmoded and "romantic" as its author. It was therefore a veritable coalition that Alibert had to face. This affair, blown out of all proportion by the press, probably took on so much importance because the political situation was explosive and Alibert represented everything to be fought against in society. At the height of the polemic in 1829, the criticism could be summed up in the sentence uttered by Alphée Cazenave (1795-1877), one of Biett's students: "To flatter a gentleman of the court is perhaps to invest in his future grandeur!"126

Alibert had nothing new to say about the sarcoptes, but he remained convinced of the existence of the mite and its role in the itch: "Should not those who seek to know the truth with a sincere heart hold their judgment? The research has to be redone".127

François-Vincent Raspail (1794-1878), a competent and acknowledged scientist especially in microscopy and histochemistry, was at the centre of these "verifications". In 1827, Raspail quarrelled with the botanist Adolphe Brongniart. Raspail became convinced that affairs of science were nothing but the machinations of elite cliques. In 1829, with his friend J F Saigey, Raspail launched his own journal, Annales des sciences d'observation,

\footnotetext{
${ }^{125}$ Steven Shapin, A social history of truth: civility and science in seventeenth-century England, Chicago and London, University of Chicago Press, 1994, pp. xxxi and 409-17.
}

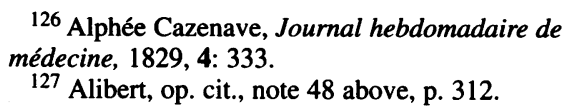

${ }^{126}$ Alphée Cazenave, Journal hebdomadaire de médecine, 1829, 4: 333.

127 Alibert, op. cit., note 48 above, p. 312. 


\section{The Missing Itch-Mite in French Medicine}

as a vehicle for a continued assault on official science. ${ }^{128} \mathrm{He}$, therefore, approached the "itch affair" in a special state of mind. At the beginning of his research, he did not believe in the existence of the itch-mite: "M Galès alone held the secret of making the mite visible, a secret he earned not by reason of his name but by his skill. Indeed, since he published his thesis, many Parisian physicians have tried in vain to find the itch insect and to observe it with their own eyes. This failure on the part of the professors where a student had been successful made the most.open-minded unbelieving". After reading the literature, however, Raspail concluded in favour of the existence of the mite because of the numerous examples of trustworthy scientists who had seen the insect. Lugol was wrong to deny the mite's existence. Yet, Raspail stressed that the mite was not present in every pustule; he had examined over 200 of them without finding it. Furthermore, he maintained that the itch was not caused by the mite; the insect had only an accessory role. Raspail also denounced Galès' deceit because he was convinced that Galès had shown a cheese-mite. Here was yet another opportunity for him to ridicule academic science as represented by the entomologists who allowed themselves to be fooled. ${ }^{129}$

Raspail was so persuaded that Galès was an impostor that he did not even mention the "inoculation" by Galès which the latter had used to show the characteristic consequences to the five "trustworthy" members of the jury: the three entomologists and two physicians. He explained, however, that the cheese-mite (or flour-mite) was not the itch-mite because, if it were, all cheesemongers would be infected with the itch. ${ }^{130}$

The entomologist Duméril (who was also a physician) hastened to respond to Raspail's accusations in a letter published in La Clinique, September 1829: "My well-known tendency to speak the truth and even to be too frank at times would force me to admit that I was mistaken, if I was. But how can somebody prove to me that I did not see what I declare to have seen several times?" Duméril said he himself had extracted the insect from human itch pustules which had been provoked by the itch-affected phascolomes of New Holland. He affirmed that the human itch-mite did, indeed, exist, but made no comment on the morphological difference between the itch-mite and the cheese-mite. Duméril was the only entomologist to respond. Galès did not react to Raspail's arguments. ${ }^{131}$

Patrix made another attempt to show the itch-mite in order to explain the contagion of the disease. After receiving Duméril's reply, Patrix invited all the protagonists at HôtelDieu hospital to his demonstration. Confident of his success, he even had the report of the session printed the day before. But the insect did not appear. Raspail took advantage of the occasion to distribute plates of Galès' insect and a few mites from stale cheese which the cheesemongers in the area sold at a very high price for a few days. The following session was also a failure. ${ }^{132}$ As a result, at the end of 1829 , not only was the role of the mite in the itch rejected, but also its very existence. ${ }^{133}$

\footnotetext{
${ }^{128}$ T A Appel, The Cuvier-Geoffroy debate: French biology in the decades before Darwin, Oxford University Press, 1987, p. 196; see also Dora B Weiner, Raspail, scientist and reformer, New York and London, Columbia University Press, 1968, pp. 73-7.

${ }^{129}$ Raspail, op. cit., note 118 above, p. 455.

${ }^{130}$ Ibid., p. 456.
}

\footnotetext{
${ }^{131}$ When the "scandal" erupted, Duméril had long since left St Louis hospital and was running a hydrotherapy clinic where the itch was treated with his sulphurous fumigations (Brodier, op. cit., note 1 above, p. 31).

132 Raspail, op. cit., note 72 above, p. 173.

133 Ibid., p. 174-5.
} 


\section{Danièle Ghesquier}

\section{The Conclusion of the Affair}

For five years (1829-34) there was silence on the itch-mite. In the meantime, the 1830 revolution removed the legitimists from power. Although Alibert swore allegiance to the new "king of the French people", he was not an Orléanist and, therefore, lost his privileged position. He ceased to be "the man to cut down" for those who thought that truth was not on the side of power. The political liberalization also, paradoxically, led to the diminishment of the importance of individuals like Broussais, who had fought against the state. The 1830 revolution brought Broussais' personal and political friends to power, and he obtained a chair in the Faculty of Medicine in Paris, and became a member of the Academy of Ethics and Political Science. This was the peak of his career, but also the beginning of the rapid decline of his influence. ${ }^{134}$ "The students no longer followed him. His doctrine had lost its momentum, and weaknesses had become obvious. Then too, listening to Broussais was no longer considered a sign of political rebellion". ${ }^{135}$ The political liberalization led to the liberalization of disease theories. ${ }^{136}$ The supporters of specificity, such as Bretonneau, received attention again. The change in attitude paved the way for the "rediscovery" of the animal itch-mite.

\section{The Itch Insect is Rediscovered}

In 1831, Raspail observed the horse itch-mite and published a description of it in $\mathrm{La}$ Lancette, 13 August. The insects "which could be seen milling about", resembled De Géer's insects, but not those shown by Galès. But as Raspail had no need to go in search of them, he did not dwell on their cutaneous localization. He simply announced that "mites would surely be found one day in the human itch pustules".

In 1834 , popular experience ${ }^{137}$ came to the rescue of academic medicine. Renucci, a medical student from Corsica attending classes in the capital, learned that the existence of the itch-mite was causing a lively controversy. He examined itch patients in Paris to make sure that the insects were found on them as they had been on patients in Corsica. He then taught physicians how to extract the insect from the tunnels in the skin: "On Wednesday, August 13, one of the most interesting sessions for the progress of Art, took place at St Louis hospital. While Prof. Alibert was busy in consultation, a Corsican student-M Renucci-among the many students who attended Alibert's class, extracted from the fingers of a woman affected with the itch, the animalcule known as acarus scabiei. The minute animal was observed without the help of a magnifying glass, just by the light of the sun." The unknown, but famous author $(\mathrm{X})$ of the communiqué asked what had

\footnotetext{
${ }^{134}$ Braunstein, op. cit., note 93 above, p. 196, see also Ackerknecht, op. cit., note 80 above, p. 66.

135 Ackerknecht, op. cit., note 80 above, p. 67.

136 Jean-Baptiste Bouillaud said that it was not possible, at that time, to expound any medical theory freely: the state exerted its power to exclude those who propounded certain doctrines, while favouring those who espoused "anti-progressive doctrines" (J B Bouillaud, Essai sur la philosophie médicale et sur les généralités de la clinique médicale, précédé d'un résumé philosophique des principaux progrès de la
}

médecine, Paris, Just Rouvier, 1836, p. 99). The Faculty of Medicine of Paris was purged in 1822 of Republicans and Bonapartists who were in the majority. The doctrines of professors had to conform more with the doctrines of Christianity ( S Jacyna, 'The politics of medicine in Restoration France', Bull. soc. Hist. Med., 1987, 40: 84-5).

${ }^{137}$ Renucci learned to extract the sarcoptes from Corsican women of the poor classes, who removed the insect from their children's skin with a pin. 


\section{The Missing Itch-Mite in French Medicine}

become of the assertions of the unbelieving physicians who were not afraid to oppose the best known entomologists. ${ }^{138}$ On 18 August, Lugol, who was one of the unbelieving doctors, strongly advised Alibert to take some rest, because he had certainly been wearied by his teaching. He recommended that Alibert avoid foreigners ${ }^{139}$ who showed him the mite, and told him to be careful, because next time he might not have the benefit of sunlight. But Lugol again offered his reward of 300 francs to the student who would show him the mite. ${ }^{140}$ On 20 August another demonstration took place in the presence of Raspail, as an expert, and he declared that it was, indeed, the human itch-mite, that is, De Géer's mite, and not the cheese-mite (Figure 1). So Renucci won the prize offered by Lugol. $^{141}$

\section{Renucci Becomes the True Discoverer of the Mite}

Suddenly, everyone claimed to have seen the cause of the itch, just as they had at the time of Galès' thesis, before the existence and the role of the insect had been challenged. ${ }^{142}$ But many people, including Raspail himself, who stuck to the old definition of a parasite, were not still convinced that the mite was the cause of the disease: "Does the insect cause the itch or is it just a parasite? . . If the pustule is always formed subsequent to the tunnel, and the tunnel is never formed after the pustule, then it is clear that the itch is the product and not the bait of the sarcoptes". 143

In 1835, Renucci presented his thesis 'Sur la découverte de l'insecte qui produit la contagion de la gale' (On the discovery of the insect which produces itch contagion), which implied that he was the true and the first discoverer of the sarcoptes:

M Renucci gave some details on the experiments he had done for 19 years. He had kept these notes for his thesis but decided to publish them so that his priority to the experiments could not be challenged. In 1815, in Corsica, he placed several mites on the feet, hands and forearms of a child. The child contracted the itch. M Renucci then extracted all the mites he could find on the child. A few remedies were enough to complete the cure. This extraction is carried out more easily on children than on adults because of the softness and transparency of the epidermis. M Renucci claimed to have repeated this experiment several times and it always worked. He pointed out that itch was more contagious in Corsica than in more northerly countries and that the mites were larger ... M Emery wrote a report of M Renucci's account for a commission. He gave the background to the discovery of the animalcule and the arguments it aroused; he retraced $M$ Galès' experiments and the general lack of belief which followed; finally, he mentioned the recent demonstration by $M$ Renucci as well as $\mathbf{M}$ Albin Gras' inoculations. The reporter raised some doubt about the veracity of the experiments which $M$ Renucci claimed to have done as early as 1815 . However, the commission, which considered that the honour belonged to $M$ Renucci for having established such a vital fact as the existence of the mite and for having dissipated the general misconception, proposed to send a letter of gratitude to the author and to place his paper in the archives. ${ }^{144}$

138 Gazette des hôpitaux, 16 Aug. 1834, pp. 385-6.

139 Lugol was being ironic because Renucci was a Corsican, but Corsica was a part of France.

${ }^{140}$ Gazette des hôpitaux, 19 Aug. 1834, pp. 389-90.

141 Raspail, op. cit., note 72 above, p. 176.

${ }^{142}$ Archives de médecine $n^{\circ} 36$, année 1834 n 6 ,
Royal Academy of Sciences, session held on 29 Sept., 1834, p. 288.

143 Raspail, op. cit., note 72 above, p. 183.

144 Archives de médecine $n^{\circ} 36,1834, n^{\circ} 6$, Royal Academy of Medicine, sessions held on 23 Sept., p. 278 , and 30 Sept. 1834, p. 280. 


\section{Danièle Ghesquier}

\section{Was Galès a Fraud?}

It is impossible to know if Galès really demonstrated the sarcoptes in his thesis, and the solution to "the itch-affair" will probably remain a mystery. However, it is possible to put forward a few suggestions. My own feeling is that Galès did not lie. First, if he did not extract the itch-insect, how could he have simulated the ulcerations? It was perhaps easy to mistake one mite for another, but, in this period, the physicians of the commission knew itch ulcerations well and, as Raspail said, the flour- or cheese-mite does not produce the itch-symptoms. ${ }^{145}$ Second, the reading of the thesis leaves a feeling of honesty and competence, and the demonstration was extremely consistent. Moreover, why should Galès say that "his" mite looked like the flour-mite, if his commission disagreed with him? Before him, Linnaeus confused the two mites, probably because the conditions for observing the small insects under the microscope were not good. But Galès did not enjoy better conditions of observation than Linnaeus. Third, Galès looked for and found the sarcoptes in the vesicles, but Bonomo (the first "discoverer" of the itch-mite's role) had done so and reported it before Galès. Galès' honesty was not questioned when the affair ended, as the examiner at the Academy of Medicine, after reading the thesis, considered the possibility that the artist had made a mistake. ${ }^{146}$ Only later, historians and physicians (Théodoridès, Crissey and Parish, Penso, Brodier, Devergie, Dujardin, etc.) reported the events as they were constructed by Raspail.

Nevertheless, there are some arguments which reinforce the hypothesis of Galès' fraud: the ease with which the two mites could be confused, the figures in Galès' thesis which were that of the cheese- flour-mite, the therapeutics used in the nineteenth century to treat the pruriginous areas of the skin which were powdered with wheat flour ("the flour only needed to be full of mites to give the impression that these were parasites that lived on the affected person"), ${ }^{147}$ Galès' silence, and perhaps also his reputation, as he was described as more concerned with money than with science. ${ }^{148}$ But all that is only conjecture.

\section{The Scientific Concept of the Itch is a Collective Construction}

The construction of the scientific concept of the itch is, I propose, an example of a collective construction of a scientific fact: Avenzoar associated a pruriginous disease of the skin with an animalcule. Bonomo and Cestoni turned Avenzoar's concept inside out and made the acarus responsible for both the disease and the contagion. Alibert determined that only one kind of scabies was caused by the acarus, Galès reproduced the disease, and finally, Renucci knew how to find the animal and was able to teach his successors how to do so. Is it possible to identify which of all these individuals was the most important in the development of the concept? Was it the person who first found the acarus? or the individual who delimited the itch clinically? or the one who indicated how

\footnotetext{
145 See the text related to note 130 above.

146 “. . . having the cheese-, flour- and itch-mite together, which were observed by MM. Bosc, Ollivier and Latreille, commissioners from the Institute, he might have jumbled the glasses which each contained an animalcule" (Archives de médecine $n^{\circ} 36,1834 n^{\circ} 6$, Royal Academy of
}

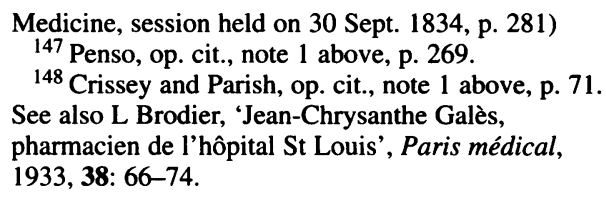




\section{The Missing Itch-Mite in French Medicine}

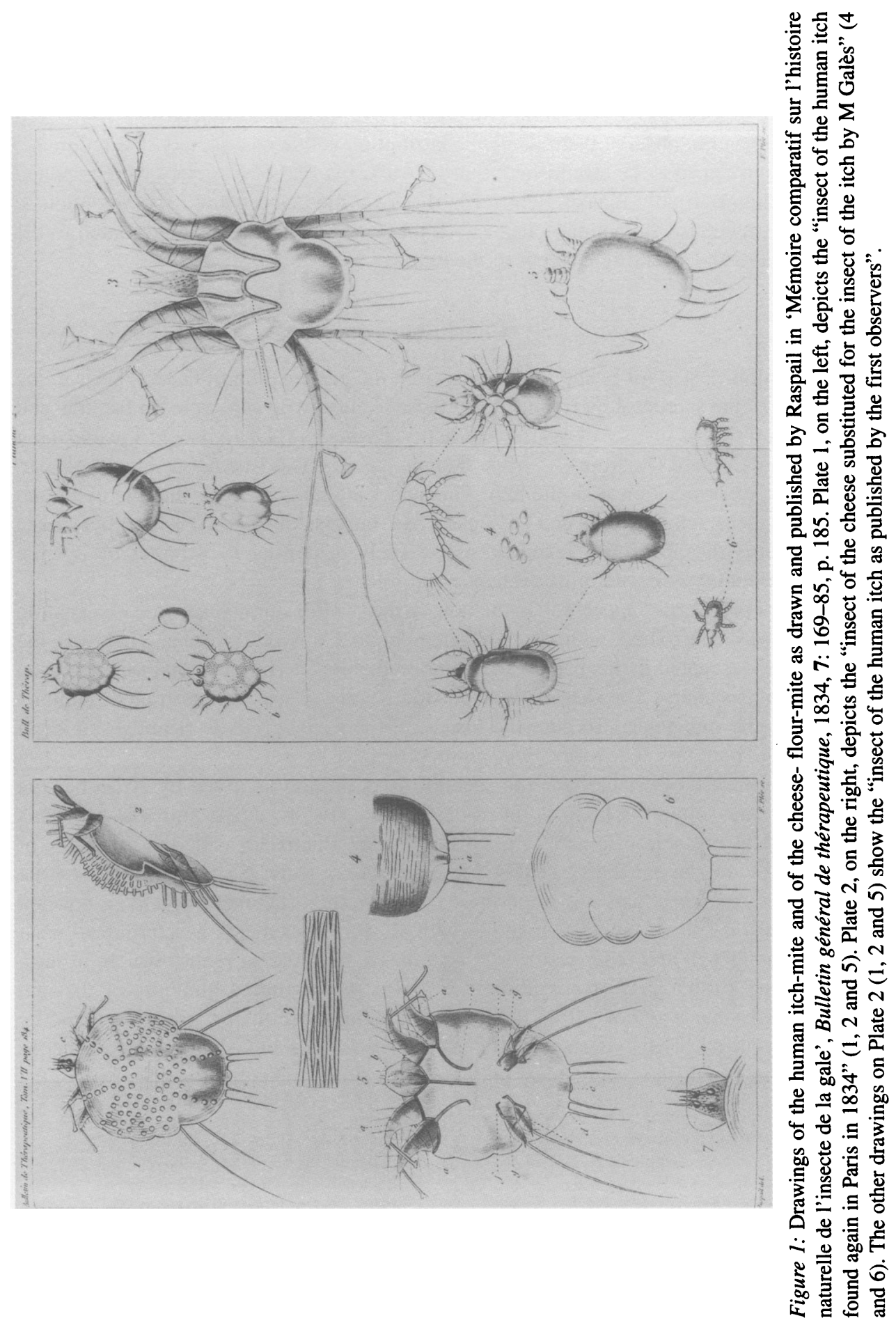




\section{Danièle Ghesquier}

to extract the sarcoptes? ${ }^{149}$ "Every theme in the sequence of ideas originates from notions belonging to the collective (effort)": ${ }^{150}$ Avenzoar's insect is a collective notion held by a medical society that believed that corrupted humours spontaneously give birth to lower animals; that of Bonomo and Cestoni is the collective view of a society that discovered insects and began to observe them; Galès' contribution is that of a society that requires a fact to be reproduced to be established; that of Alibert is that of a society which created clinical medicine; finally that of Renucci is that of a medicine which pays attention to observations made by the popular classes. All these collective notions contributed to the development of the scientific concept of the itch.

\section{Conclusion}

The itch affair lasted for twenty-two years, from the presentation of Galès' thesis to the rediscovery of the sarcoptes by Renucci. But these twenty-two years were, in fact, the end of seven centuries of history of acarus and itch vicissitudes ("Le roman de l'acare" as it was called by Bernard Dujardin), ${ }^{151}$ from the time the mite was first noticed by Avenzoar, to its definitive association with the itch. This paper attempts to show that the evolution of scientific ideas, not only between 1812 and 1834, but also during seven centuries, made the itch acarus disappear and reappear successively according to whether or not the medical community believed in its existence and role.

As soon as the acarus "appeared" in the itch, in the twelfth century, the true explanation of its role was confronted with many epistemological obstacles. ${ }^{152}$ The first was the disease theory accepted in this period, the humoral theory. ${ }^{153}$ The cause of disease was an imbalance of humours. The disease was not the acarus, it was the corrupted humours produced in the imbalance. To cure the disease, it was enough to re-establish the right balance of the humours. The acarus was unimportant.

Linked to the first obstacle was the second, its definition as given by Aristotle: the parasite is "an animal which is born spontaneously in other animals". 154 This epistemological obstacle originates from what Gaston Bachelard calls the difficulty of casting doubt on the ancients' genius for observation. Any such doubts led to the accusation of disrespect and self-importance. ${ }^{155}$ Aristotle's statement became a concept "which creates habits of thought. Together with all other statements it determines 'what cannot be thought in any other way'. . It becomes a self-evident reality which, in turn, conditions our further acts of cognition". ${ }^{156}$ It was the corrupted humours of the itch which created what was not yet an animal but nothing more than a group of aspecific "living molecules". The existence of the parasite was thus linked to the spontaneous generation theory which was prevalent until Pasteur's time. ${ }^{157}$ Neither the discovery of the

\footnotetext{
${ }^{149}$ Bruno Latour and Steven Woolgar, Laboratory life: the construction of scientific facts, 2nd ed., Princeton University Press, 1986, p. 178.

${ }^{150}$ Ludwik Fleck, Genesis and development of a scientific fact, Chicago and London, University of Chicago Press, 1979, p. 41.

${ }_{151}$ Dujardin, op. cit., note 1 above.

152 Gaston Bachelard, La formation de l'esprit scientifique, Paris, Vrin, 1980.
}

\footnotetext{
${ }^{153}$ Laharie, op. cit., note 62 above, pp. 120-2.

${ }^{154}$ Aristotle, op. cit., note 14 above.

155 Bachelard, op. cit., note 152 above.

156 Fleck, op. cit., note 150 above, p. 37.

157 John Farley and Gerald L Geison, 'Science, politics and spontaneous generation in nineteenthcentury France: the Pasteur-Pouchet debate', Bull. Hist. Med., 1974, 48: 161-98.
} 


\section{The Missing Itch-Mite in French Medicine}

specificity of lower animals, nor the observations that they were causes of specific diseases, were enough to discredit this theory which was strongly linked to the humoral theory of disease. Raspail's idea that the itch-sarcoptes might be the "parasite" of the itch instead of its cause, is evidence of this attitude in 1834. By the 1860s, Davaine's experiments on anthrax showed that the concept of the parasite was still used to counter the theory of contagion. ${ }^{158}$ If the itch-acarus was accessory, this would explain why it was absent from medical thought until the seventeenth century.

In the seventeenth century, the interest in microscopic animals made the acarus appear in the scientific field. The concept of parasite was attacked for the first time. However, no more importance was given to the role of the acarus as "the" cause of the itch. The specificity of the disease was not constructed on a specific and necessary cause, for this concept did not exist in the eighteenth century. The concept used by physicians until the middle of the nineteenth century was that of the sufficient cause, and not that of the necessary cause. ${ }^{159}$ This was the third obstacle for the itch-acarus, which was only one of the causes of the disease, one of the causes of "contagion"; but to accept contagion did not mean that the author regarded contagia as necessary, even for diseases that were generally recognized as contagious: "In the 1840s, typical European obstetricians identified both contagia and epidemic influences as well as deprivation, worry, shame, attempted abortion, fear of death, dietary disorders, exposure to cold, local miasmas, difficult delivery, and retention and decomposition of the placenta as possible causes of puerperal fever". ${ }^{160}$ On the other hand, there was no link between a cause and its effect, and because the causes of diseases were believed to be numerous, the same cause of disease could result in various effects, special or typical according to places, events, or the organic tendencies met. ${ }^{161}$ Thus, until the concept of necessary causation was established, the itchacarus could not play a significant part in the genesis of the itch. Alibert was one of the few scientists who believed in the acarus as a necessary cause of the itch; he made the insect reappear for Galès' thesis.

The fourth obstacle confronting the itch-acarus, which became important only at the beginning of the nineteenth century, was that of the contagion model, smallpox, and particularly that of the analogy between the pustules of smallpox and those of the itch. It was this analogy and the confusion made by Galès' contemporaries between the vesicles and the pustules, which made the acarus disappear after Galès' thesis. This was the reason why Alibert called the itch, pustular psora. The pustule was the expected location for the itch insects from Duméril's phascolomes, and that for Raspail's itch insects from horses and humans. In 1812, Galès did not contradict the model when he found the insect in the vesicles of the itch, since vesicles are, like pustules, pimples of the itch. It was only by the $1820 \mathrm{~s}$, when the criteria for contagion became very strict, that observers looked for the sarcoptes in the pustules in order to make the itch conform to the smallpox model. But everything went wrong when the insect was not in the pustule, since the itch deviated from the model and did not fit any existing theory. This epistemological obstacle corresponded to the need for uniformity in science: "It is often repeated that science is greedy for

\footnotetext{
${ }^{158}$ L'oeuvre de C-J Davaine, Paris, J-B Baillière et fils, 1889 , pp. $521-40$.

${ }^{159} \mathrm{~K}$ Codell Carter, 'The development of Pasteur's concept of disease causation and the emergence of
}

specific causes in 19th century medicine', Bull. Hist. Med., 1991, 65: 528-48, p. 528.

${ }^{160}$ Carter, op. cit., note 88 above, p. 370.

${ }^{161}$ Fantini, op. cit., note 32 above, p. 77. 


\section{Danièle Ghesquier}

uniformity, that it tries to identify phenomena of various appearances, that it searches for simplicity or economy of principles or methods. This uniformity would be found quickly, if science could take pleasure in it". ${ }^{162}$

After Galès' thesis, when the itch was considered specific only if it conformed closely to the smallpox model, a new obstacle appeared: smallpox itself became non-specific. Henry Cohen said that "two main ideas have been dominant: disease as an entity that befalls a healthy person, and disease as a deviation from the normal". ${ }^{163}$ Broussais supported the second idea. The causes of the disease which were already seen as multiple, accessory, and "separated" from their effect, became even more secondary when the accent was put on the disturbed function. If syphilis and smallpox did not depend on contagion, why should the itch depend on it? The sarcoptes, which did not belong to any system, became then impossible to find.

About twenty years after Galès' thesis, there was another change in the concept of disease causation. Specificity reappeared, making possible again the specificity of the itch. It could be said that the reappearance of the itch-acarus was the very beginning of this change in concept from sufficient to necessary cause of disease. ${ }^{164}$ That would signify that Davaine was not the first to think that a specific factor is the cause of a particular disease (what Koch put in concrete form in his postulates). Bonomo, Alibert and Galès, when insisting that the itch was caused only by the acarus, made it the necessary cause of the disease, and outlined the idea that some specific diseases had one cause and one cause only. ${ }^{165}$

Did the rediscovery of the sarcoptes in 1834 mean that "right" triumphed easily thereafter and that the role of sarcoptes was recognized and accepted entirely, or were some objections maintained?

Twenty years after the end of the "affair" (1852), Alphonse Devergie (1798-1879), another of the St Louis hospital physicians, again thought about the itch in humoral terms: the itch was the eruption which "spontaneously" produced the acarus. Devergie again supported the acarus venom theory, injecting pulverized acari to find evidence of general poisoning. ${ }^{166} \mathrm{But}$, a few years later (1855), the itch was classified in Zooparasitic specific eruptions, close to phytoparasitic specific eruptions like tinea, and close to virulent specific eruptions like syphilis and to epidemical virulent specific eruptions like smallpox, scarlet fever and measles. Rollet, chief-surgeon at the Antiquaille Hospital of Lyon, the author of this classification, separated parasites like the itch-acarus and microscopic fungi from other contagious agents of skin diseases, namely the "viruses" which induced smallpox and measles. ${ }^{167}$ It seemed established that transmission of all the specific skin diseases could be explained by multiplication of the agents; but, in the case of "viruses" this statement was still speculative; if "viruses" were seen as living material, the relationship with animalcules was not yet made. ${ }^{168}$ The "virus" was still in the "darkness" from which the itch-acarus had re-appeared.

\footnotetext{
162 Bachelard, op. cit., note 152 above, pp. 23-54.

$163 \mathrm{H}$ Cohen, 'The evolution of the concept of disease', in Brandon Lush (ed.), Concepts of medicine, Oxford, Pergamon Press, 1960, p. 160.

${ }^{164}$ Carter, op. cit., note 88 above.

165 Carter, op. cit., note 159 above, p. 548.

${ }^{166}$ Devergie, op. cit., note 1 above, p. 430.
}

\footnotetext{
167 'Classifications des maladies de la peau' (Leçon recueillie au cours de M Rollet, chirurgien en chef de l'Antiquaille), Gazette médicale de Lyon, 1855 , pp. 284-92.

${ }^{168} \mathrm{M}$ Rollet, 'Des agents contagieux des maladies de la peau', Gazette médicale de Lyon, 1855 , pp. 28-32.
} 